\title{
Biofilm producing bacteria: A serious threat to public health in developing countries.
}

\author{
Umber Tasneem*, Nusrat Yasin, Iqbal Nisa, Faisal Shah, Ubaid Rasheed, Faiza Momin, Sadir Zaman, Muhammad \\ Qasim
}

Department of Microbiology, Kohat University of Science and Technology, 26000, Khyber Pakhtunkhwa, Pakistan

\begin{abstract}
Microorganisms adhere themselves with different surfaces like indwelling medical devices, equipment's of different industries like water, food and dairy products etc. Microorganisms after attachment produce EPS, which help them in the development of biofilms. Commonly known pathogens including, bacteria, fungi, viruses, protozoa and pathogenic cyanobacteria, are involved in biofilm formation. Biofilms are involved in many persistent and chronic infections in human and animals, increase resistance to antimicrobials, biofouling of water and spoilage or contamination of food and dairy products etc. Biofilms producing bacteria is a serious threat for public health globally but due to poor sanitary conditions and low economic resources chances of infections is high in developing countries. Effective control measures should be developed for the treatment and prevention of biofilm to get rid of serious problems.
\end{abstract}

Keywords: Biofilm, EPS, Pathogens, Public health.

\section{Introduction}

Initially pathogens appeared in human communities, and spread to areas where they are not previously found are called enteric pathogens. These pathogens include: bacteria (E. coli, $H$. pylori, C. jejuni, M. avium complex), protozoa (C. cayetanensis, Cryptosporidium spp., Toxoplasma gonidii), viruses (noroviruses, Hepatitis E viruses) and pathogenic Cyanobacteria [1]. Approximately $99 \%$ of micro-organisms on planet earth live in communities known as biofilms [2]. Biofilm forming organisms are quietly broad in nature containing number of known pathogenic fungi and bacteria [3]. Due to biofilm formation pathogenic bacteria are not only capable of causing infection but they are also capable to survive in diverse environmental condition [4]. Microbial biofilms were first observed by Van Leeuwenhoek, on the surface of tooth [3]. Microbial biofilms were also studied by Characklis in water systems of industry and observed that biofilms are anti-susceptible to disinfectants like chlorine [5].

Microorganisms of multiple groups also constitute same biofilm, in which interstitial spaces and water channels are present for the transport of oxygen and nutrients, which help in the development of cells present in biofilm [6]. Recently, evidence shows that biofilms contain virulence factors, which help resident bacteria to attain virulence characters that are not present in single bacteria [7].

A biofilm constitute of many microbial cells associated with surface, present in an Extracellular Polymeric Substance (EPS) matrix. Biofilms are present on different surfaces, like biological tissues, medical equipments, pipes of water systems etc. [3]. Formation of biofilms depends on the type of microorganisms and material [6]. Biofilms have a tendency to trap particles, including various minerals and components of host system such as, RBCs, fibrin and platelets.
Biofilm-containing organisms develop slowly as compared to planktonic organisms [8]. Important characteristics of biofilm are; aggregation of biofilm with cells, exchange of resistance plasmids between cells, production of endo-toxins, resistance to antimicrobials and host defense system clearance $[9,10]$. Kind of substrate, cell surface hydrophobicity which help them in attachment with pilli, flagella, glycocalyx and fimbriae are also an important characteristics of biofilm [3,11].

In developing countries a disturbing feature of biofilm-based infections is higher resistance to antibiotics [12]. However, they also cause industrial pipe fouling, plant infections and nosochomial infections, causing great economic problems in industry and medicines [9,13-15]. There are many improved stratergies for biofilm control but due to collapse of current techniques new procedures are urgently required [16].

\section{Role of biofilm in public health}

Biofilm are present everywhere in nature and can cause important problems in non-medical areas (For example, biofouling in potable water environment and food handling systems) and medical areas (For example; continual and repeated infections and infections related to medical device) $[17,18]$.

\section{Non-Medical Areas}

\section{Biofouling of water}

Water is an important component of life. Adequate and secure water must be accessible to all, which result in many health benefits [19]. Microbial contamination results in many health related problems [20]. Many serious health issues are facing in developing countries related to safe drinking water, like diarrhea and death specially in infants. Primarily in Asian and African countries [21]. According to $\mathrm{WHO}$, death rate due to water born infections exceeds 5 million people per year, in which more than $50 \%$ are intestinal infections? Cholera ranks 
first in people of low economic resources and poor hygienic conditions [19,21,22]. This issue is also sensitive in pregnant women, young children's and elder persons [23].

Biofouling in industrial and drinking water has harmful effects such as chemical and microbiological destruction in water quality, inducing, yield loss, reduction in efficiency of heat transport and exchange and in membrane techniques [24,25]. Opportunistic pathogens, viruses, parasitic protozoa, toxin releasing algae and fungi and enteric bacteria e.g. E. coli, $K$. pneumoniae, $K$. oxytoca, E. cloacae, E. aglomerans, $H$. pylori, Shigella spp., Campylobacter spp., Salmonella spp., C. perfringens, E. faecium, E. faecalis and environmental pathogenic bacteria like L. pneumophila, P. aeruginosa, P. fluorescens, A. hydrophila, A. caviae, M. avium, M. xenopi etc. are associated with biofilms present in drinking water. These biofilms are complex, containing clay material, corrosion products, filamentous bacteria and fresh water diatoms $[3,26]$. They may materialize as primary colonizers, which help them in adhesion and biofilm formation [27]. These biofilms cause problems in colour, taste and odor due to release of chemical compounds and more significant they cause a threat to animal and human health [20]. Due to these problems, natural biofilms make contact with drinking water were recognized and described as reservoirs of microorganisms for further infectivity [25,28].

\section{Biofilm formation in food industry}

Bacteria, including foodborne pathogens grow as biofilms in their normal habitats [29,30], leading to severe hygienic problems and economic loss due to spoilage of food. The growth of microbes on solid surfaces is a universal fact [31], which is an important factor of food-borne infections and biofilm development when not properly sterilized [32]. The ability of bacteria to adhere with surfaces is more implicated in many industries [33] especially pharmaceutical and food [34], in which L. monocytogenes is a common one [35]. Safety of food is an important public health issue that connects human wellbeing to different areas of food manufacturing like farming etc. [36].

\section{Ready-to-eat food}

People in many countries use ready-to-eat (RTE) and raw food, including products of seafood [36]. Second most common food borne pathogen in RTE was E. cloacae [29,35]. Similarly the most common pathogen in poultry farm is $\mathrm{S}$. enteritidis which cause food poisoning in human worldwide. Biofilm is produced by almost $50 \%$ of them [37].

\section{Sea food}

Foodborne infections due to consumption of seafood are a major cause of the worldwide hospitalizations and morbidity $[38,39]$ because nutritional value of seafood is high, containing proteins, omega-3 fatty acids, micronutrients, minerals and vitamins [40,41]. Seafood includes species of marine mammals, mollusks, finfish, fish eggs and crustaceans [35]. Pathogens forming biofilm are generally resides in certain types of seafood, such as crabs [42], pacific oysters [43] and shrimp [44] etc. Seafood-related infections are caused by numerous viruses, bacteria, and parasites [35], forming biofilms on food contact surfaces, seafood, and in water [45] where they remain attached for long time [46] and show resistance to many antimicrobials $[47,48]$. When these biofilms are stirred by food-related and environmental factors, they come again to their planktonic state [49].

Common pathogens cause contamination in fish and seafood are A. hydrophila is most widely known specie [50,51] and an etiological agent of antibiotic and virulence resistance [52]. V. cholera is also an important source of seafood contamination i.e. diarrhea [53], during handling, manufacturing and processing $[54,55]$. Cholera has been known as the main cause of diarrhea in South East Asia [56-58] Haiti [59], Africa [60] and other developing countries [61]. In 1992, outbreak of V. cholera O139 was first reported in India and Bangladesh [62].

Salmonella spp. cause infections in poultry, seafood, dairy products, pork and beef $[63,64]$, also at high salt and temperature [64-667], therefore it is a major challenge worldwide [67]. L. monocytogenes is an important pathogen, and was present in freshwater fish, crabs and catfish $[68,69]$. After contamination in food, this pathogen can also multiply at refrigeration temperatures [70].

\section{Threats of biofilms in dairy industry}

Due to change in situation of global marketplace, the dairy industry becomes of the major industry of the world in which perishable (e.g. yogurt, butter and cheese) and semi perishable (casein, milk powder) products are manufactured. Inadequate cleaning and sanitization help pathogens to make biofilm in milk processing units [47,71], causing both public health and economic loss. Instead of sanitation and cleaning process, it has been noticed that microorganisms can remain stay on the surface of equipment [72]. Biofilms are not only a way of contamination, but it can also reduce transfer of heat, increase rate of corrosion and resistance to friction of fluid [73]. Bacterial growth in dairy products can badly affect their functionality, quality and safety [74]. In dairy industries the most commonly occuring bacteria belong to the genus Enterobacter, Micrococcu, Listeria, Streptococcus, Bacillus and Pseudomonas [75-77].

Because of neutral $\mathrm{pH}$ and nutritive nature, milk is the most excellent medium for the reproduction of microorganisms [74]. Species like Pseudomonas, Legionella and Aeromonas originating from rinsing water also cause contaminations in dairy products. Other sources of contamination are formation of biofilms in milk pipelines, milk silos and storage tanks [78].

In ultra-heat-treated (UHT) milk common contaminants are Pseudomonas spp., especially P. lundensis, P. fragi and P. fluorescens [79,80]. These species produce heat labile extracellular proteases, lipases and lecithinases that cause spoilage of milk. Biofilms on food and dairy equipment caused contamination after processing, that decrease shelf-life of product and spread possible diseases [81].

\section{Biofilms and Infectious Diseases}

Biofilms are responsible for a large number of microbial diseases in both animals and humans [82].

\section{Infections in animals}

Biofilm is also associated with many animal diseases. So role 
of biofilm should be carefully studied in the field of zoology. Important topics like food safety, animal welfare and health, animal disease control are extremely dependent on the ability to control bacterial quorum sensing and biofilm [83].

\section{Infections in humans}

Public health and clinical microbiologists recognizes that biofilms are present everywhere in nature and cause number of human infections [83]. Infectious due to biofilm mainly include urinary tract infections (UTI), middle-ear infections, catheter infections, dental plaque, coating contact lenses, gingivitis, endocarditis, cystic fibrosis and infections of persistent indwelling devices such as heart valves and joint prostheses $[84,85]$. Many UTI and bloodstream infections are caused due to biofilm associated indwelling medical devices [86]. Chronic infections, inflammation and tissue damage caused by many strains of single species are often found in polymicrobial communities [14].

Several protozoa, bacterial and fungal biofilms are related to $60 \%$ urinary tract infections $[87,88]$. H. pylori is the most common cause of infections in humans after S. mutans [89], causes diseases in $20 \%$ of infected persons [90]. If UTI are not properly treated then other complications may also be develop such as bacteremia, acute pyelonephritis, bacterial prostatitis and vaginosis, renal infections, bladder cancer and sometime death $[6,10,91]$.

\section{Medical Devices}

Opportunistic organisms are causative agent of diseases that ranges from simple allergy to systemic infections affecting worldwide population [92]. Biofilms may be of a single or multiple species, depending on the conditions. Biofilms of Urinary catheter biofilm may be initially composed of single spp., but with the passage of time it may be of multi-specie Common bacteria isolated from indwelling medical devices are E. faecalis, S. aureus, S. epidermidis, S. viridans, E. coli, $K$. pneumoniae, P. mirabilis, and P. aeruginosa [93]. Among these S. epidermidis and $S$. aureus are commonly present on cardiovascular devices [94], causing about $40 \%-50 \%$ of infections related to heart valve and $50 \%-70 \%$ of infections related to catheter (Figure 1) [95].

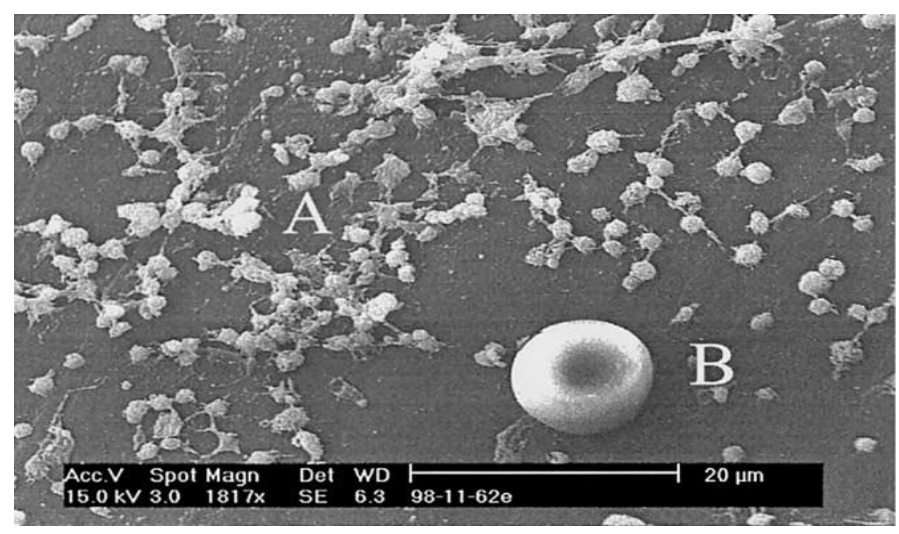

Figure 1. Staphylococcal biofilm (A) containing an $R B C(B)$ on the surface of a needle less connector. (Scanning electron microscope micrograph by Janice Carr, Centers for Disease Control and Prevention [Atlanta].

\section{Antimicrobial Resistance}

The innovation of penicillin is considered as a golden age in the field of medicines is because it focused on a new era in the prevention and treatment of lethal diseases [96]. With the passage of time new antibiotics were also discovered like chloramphenicol, streptomycin and tetracycline. These antibiotics were first used during World War II [97]. However, with the passage of time and increasing use of antimicrobials, more bacteria developed resistance against them [98].

Bacteria associated with biofilm are more resistant to antimicrobials, because the complex structure of biofilm with EPS matrix prevents the access of antibiotics to bacteria. Due to change in environmental conditions bacteria in biofilm grow slowly or would be deprived from nutrition and gathering of waste. These changed state could make bacteria more antisuseptible to antibiotics, which results chronic and persistent infections [36,99]. Methicillin resistance in S. epidermidis and $S$. aureus (MRSA) is one of the main problem in medical field [100-102].

The mechanism of resistance in biofilm remain not completely understood [103], but for the prevention of biofilm an enzyme (e.g. alginate lyase and DNase) and quorum-sensing inhibitors related techniques are used, which help in the dissolvation of EPS matrix that increase antibiotic resistance towards biofilm [104].

\section{Control}

Many microbial biofilm control methods containing limited water and nutrients supply, controlled temperature, and welldesigned apparatus are required for safety of both non-medical and medical areas [31]. The main technique used to stop biofilm formation is disinfection and cleaning of surfaces on which bacteria get attached $[105,106]$. Chemicals commonly used in disinfection processes are acidic compounds, caustic products, aldehyde-based biocides, hydrogen peroxide, chlorine, iodine, ozone, isothiazolinones, phenolics, peracetic acid, surfactants and biguanidines, [107,108]. Removing biofilms through sanitation and cleaning techniques is tremendously challenging [12]. Numerous processes to control biofilm are now available e.g. use of chitosan, probiotics, plant extracts, organic acids, bacteriocins, ethylenediaminetetraacetic acid (EDTA), and oils such as cinnamon $[109,110]$. Mechanical treatment can also be applied with chemical agents to disinfect and remove biofilms [75].

\section{Conclusion}

Biofilm is a serious threat in public health in developing countries, because it is an example of defense mechanism in numerous bacteria. Biofilm are made by different species in their own unique way. Biofilms in drinking water, food/dairy industries are associated with many microbial pathogens, which affect the quality and quantity of food products and biofouling of water. The supply of contaminated water and food may be a threat to human and animal health. In developing countries, provision of safe and clean water/food is a major global subject, which increases the rate of infections in these countries. Growth of biofilms depends on many biotic and abiotic factors. If we 
Citation: Tasneem U, Yasin N, Nisa I, et al. Biofilm producing bacteria: A serious threat to public health in developing countries. J Food Sci Nutr. 2018;1(2):25-31.

control these factors through different techniques, growth of microbial biofilm can be stopped up to certain limit, which reduces the chance of infections.

\section{Future Prospective}

Further research on biofilm related public health issue is needed to prevent and control infections related to drinking water industries, food industries and dairy industries. Research on this aspect should be proceed on many areas including, removal of genes expressed by organisms associated with biofilm, assessment of different control mechanisms for remediation of biofilms that colonize on medical devices and decrease antimicrobial resistance etc.

\section{References}

1. Hunter PR, Payment P, Ashbolt N, et al. Assessment of risk, In: Assessing microbial safety of drinking water, IWA Publishing, London, UK. 2003.

2. Victoria OA, Tajudeen O I. Crystal Violet Binding Assay for Assessment of Biofilm Formation by Listeria monocytogenes and Listeria spp. on Wood, Steel and Glass Surfaces. Global Veterinaria. 2011;6(1):6-10.

3. Rodney MD. Biofilms: Microbial Life on Surfaces. Emerg Infect Dis. 2002;8(9):881-90.

4. Hall-Stoodley L, Costerton JW, Stoodley P. Bacterial biofilms: from the natural environment to infectious diseases. Nat Rev Microbiol. 2004;2(2):95-108.

5. Characklis WG. Attached microbial growths-II. Frictional resistance due to microbial slimes. Water Res. 1973;7(9):1249-58.

6. Tenke P, Koves B, Nagy K, et al. Update on biofilm infections in the urinary tract. World J Urol. 2012;30(1):51-7.

7. Hu FZ, Ehrlich GD. Population-level virulence factors amongst pathogenic bacteria: relation to infection outcome. Future Microbiol. 2008;3(1):31-42.

8. Donlan RM. Role of biofilms in antimicrobial resistance. ASAIO J. 2000;46(6):S47-52.

9. Rogers J, Dowsett A, Dennis P et al. Influence of plumbing material on biofilm formation and growth of Leuginells pneumophila in potable water. Appl. Environ Microbiology. 1994;60(1):842-51.

10. Guiton SP, Hung SC, Hancock LE, et al. Enterococcal biofilm formation and virulence in an optimized murine model of foreign body-associated urinary tract infections. Infect Immun. 2010;78(10):4166-75.

11. Christensen GD, Baldassarri L, Simpson WA. Colonization of medical devices by coagulase-negative staphylococci. In: Bisno AL, Waldvogel FA, eds, 1994. Infections associated with indwelling medical devices, 2nd ed. Washington, DC: American Society for Microbiology, pp: 45-78.

12. Hoiby N, Bjarnsholt T, Givskov M, et al. Antibiotic resistance of bacterial biofilms. Int J Antimicrob Agents. 2010;35(4):322-32.
13. Danhorn T, Fuqua C. Biofilm formation by plant associated bacteria. Annu Rev Microbiol. 2007;61:401-22.

14. Hall-Stoodley L, Stoodley P. Evolving concepts in biofilm infections. Cell Microbiol. 2009;11(7):1034-43.

15. Costerton JW, Cheng KJ, Geesey GG. Bacterial biofilm in nature and disease. Annu Rev Microbiol.1987;41:435-64.

16. Simoes M, Cleto S, Simoes LC et al. Microbial Interactions in Biofilms: Role of siderophores and iron dependent mechanisms as bio-control strategies. Marsh P Caries res. 2003;38:204-11.

17. Fux CA, Costerton JW, Stewart PS, et al. Survival strategies of infectious biofilms. Trends Microbiol. 2005;13(1):34-40.

18. Rao V, Ghei R, Chambers Y. Biofilms ResearchImplications to Biosafety and Public Health. Applied Biosafey. 2005;10(2):83-90.

19. WHO. Guidelines for Drinking-water Quality, Incorporating 1st and 2nd Addenda, Volume 1, Recommendations, $3^{\text {rd }}$ ed, WHO: Geneva, Switzerland 2008.

20. Riley MR, Gerba CP, Elimelech M. Biological approaches for addressing the grand challenge of providing access to clean drinking water. J Biol Eng. 2011;5(1):2.

21. Grabow WOK. Waterborne Diseases: Update on Water Quality Assessment and Control. Water SA. 1996;22(2):193202.

22. Seas C, Alarcon M, Aragon JC, et al. Surveillance of Bacterial Pathogens Associated with Acute Diarrhea in Lima, Peru. Int J Infect Dis. 2000;4(2):96-9.

23. Reynolds KA, Mena KD, Gerba CP. Risk of waterborne illness via drinking water in the United States. Rev Environ Contam Toxicol. 2008;192:117-58.

24. White DC, Kirkegaard RD, Palmer RJ, et al. The biofilm ecology of microbial biofouling, biocide resistance and corrosion, In: Biofilms in the aquatic environment, Keevil CW, Godfree A, Holt D, Dow C (ed), The Royal Society of Chemistry, Cambridge, UK, pp: 120-30.

25. Wingender J, Flemming HC. Biofilms in drinking water and their role as reservoir for pathogens. Int J Hyg Environ Heal.2011;214(6):417-23.

26. Costerton JW. Structure of biofilms, In: Biofouling and biocorrosion in industrial water systems, Geesey GG, Lewandowski Z, Flemming HC (eds.) CRC Press, ISBN 087371928 X, USA1994.

27. Environmental Protection Agency (EPA), US. Health Risks from Microbial Growth and Biofilms. Office of Ground Water and Drinking Water Standards and Risk Management Division. 2002.

28. Szewzik U, Szewzyk R, Manz W, et al. Microbiological safety of drinking water. Annu Rev Microbiol. 2000;54:81127.

29. Nyenje ME, Odjadjare CE, Tanih NF, et al. Foodborne pathogens recovered from ready-to-eat foods from roadside 
cafeterias and retail outlets in Alice, Eastern Cape Province, South Africa: public health implications. Int J Environ Res Public Health. 2012;9(8):2608-19.

30. Kusumaningrum HD, Riboldi G, Hazeleger WC, et al. Survival of foodborne pathogens on stainless steel surfaces and cross-contamination to foods. Int $\mathrm{J}$ Food Microbiol. 2003;85(3):227-36.

31. Brooks JD, Flint SH. Biofilms in the food industry: problems and potential solutions. Int J Food Sci Technol. 2008;43(12):2163-76.

32. Chmielewski RAN, Frank JF. Biofilm formation and control in food processing facilities. Compr Rev Food Sci Food Saf. 2003;2(1):22-32.

33. Houdt RV, Michiels CW. Biofilm formation and the food industry, a focus on the bacterial outer surface The Society for Applied Microbiology, Journal of Applied Microbiology Global Veterinaria 2011;6 (1):6-10.

34. Payment P, Robertson W. The microbiology of piped distribution systems and public health, In: Safe piped water: Managing Microbial Water Quality in Piped Distribution Systems, Ainsworth R (ed), IWA Publishing, London, UK. 2004.

35. Mogha KV, Shah NP, Prajapati JB, et al. Biofilm - A threat to dairy industry. Indian J Dairy Sci. 2014;67(6).

36. Iwamoto M, Ayers T, Mahon BE, et al. Epidemiology of seafood associated infections in the United States. Clin Microbiol Rev. 2010;23(2):399-411.

37. Marine C, Hernandiz A, Lainez M. Biofilm development capacity of Salmonella strains isolated in poultry risk factors and their resistance against disinfectants. Poult Sci. 2009;88(2):424-31.

38. Centers for Disease Control and Prevention (CDC), 2012. Multistate Outbreak of Salmonella bareilly and Salmonella nchanga. Infections Associated with a Raw Scraped Ground Tuna Product (accessed, 02.10.12.). http://www.cdc.gov/ salmonella/bareilly-04-12/index.html

39. Butt AA, Aldridge KE, Sanders CV. Infections related to the ingestion of seafood Part 1: viral and bacterial infections. Lancet Infect Dis. 2004;4(4):201-12.

40. Hastein T, Hjeltnes B, Lillehaug A, et al. Food safety hazards that occur during the production stage: challenges for fish farming and the fishing industry. Rev Sci Tech. 2006;25(2):607-25.

41. Mahaffey KR, Clickner RP, Jeffries RA. Methylmercury and omega-3 fatty acids: co-occurrence of dietary sources with emphasis on fish and shellfish. Environ Res. 2008;107(1):20-9.

42. Reguera G, Kolter R. Virulence and the environment: a novel role for Vibrio cholerae toxin-coregulated pili in biofilm formation on chitin. J Bacteriol. 2005;187(10):3551-5.

43. Aagesen AM, Phuvasate S, Su YC et al. Persistence of Vibrio parahaemolyticus in the Pacific oyster, Crassostrea gigas, is a multifactorial process involving pili and flagella but not type III secretion systems or phase variation. Appl Environ Microbiol. 2013;79(10):3303-5.

44. Norhana MNW, Poole SE, Deeth HC, et al. The effects of temperature, chlorine and acids on the survival of Listeria and Salmonella strains associated with uncooked shrimp carapace and cooked shrimp flesh. Food Microbiol. 2010;27(2):250-6.

45. Shikongo-Nambabi MNNN, Shoolongela A, Schneider M. Control of bacterial contamination during marine fish processing. J Biol Life Sci. 2012;3(1):1-17.

46. Flood JA, Ashbolt NJ. Virus-sized particles can be entrapped and concentrated one hundred fold within wetland biofilms. Adv Environ Res. 2000;3(4):403-11.

47. Jahid IK, Han N, Ha SD. Inactivation kinetics of cold oxygen plasma depends on incubation conditions of Aeromonas hydrophila biofilm on lettuce. Food Res Int. 2014;55:181-9.

48. Srey S, Jahid IK, Ha SD. Biofilm formation in food industries: a food safety concern. Food Control. 2013;31(2):572-85.

49. Takahashi H, Miya S, Igarashi K, et al. Biofilm formation ability of Listeria monocytogenes isolates from raw readyto-eat seafood. J Food Prot. 2009;72(7):1476-80.

50. Food and Drug Administration (FDA). Bad Bug Book: Foodborne Pathogenic Microorganisms and Natural Toxins Handbook Aeromonas hydrophila. 2013.

51. Aberoum A, Jooyandeh H. A review on occurrence and characterization of the Aeromonas species from marine fishes. World J Fish Mar Sci. 2010;2(6):2078e4589.

52. Grim CJ, Kozlova EV, Sha J, et al. Characterization of Aeromonas hydrophila wound pathotypes by comparative genomic and functional analyses of virulence genes. MBio. 2013;4(2): e00064 -13.

53. Dutta NK, Pause MW, Kulkarni DR. Role of cholera toxin in experimental cholera. J Bacteriol. 1959;78(4):5.

54. Blackstone GM, Nordstrom JL, Bowen MD et al. Use of a real time PCR assay for detection of the ctxA gene of Vibrio cholerae in an environmental survey of Mobile Bay. J Microbiol Methods. 2007;68(2):254-9.

55. Suner J, Ross T. A semi-quantitative seafood safety risk assessment. Int J Food Microbiol. 2002;77(1-2):55-9.

56. Siddiqui FJ, Bhutto NS, von Seidlein L, et al. Consecutive outbreaks of Vibrio cholera O139 and V. cholera O1 cholera in a fishing village near Karachi, Pakistan. Trans R Soc Trop Med Hyg. 2006;100(5):476-82.

57. Lenglet A, Khamphaphongphane B, Thebvongsa $\mathrm{P}$, et al. A Cholera epidemic in Sekong Province, Lao People's Democratic Republic. J Infect Dis. 2010;63(3):204-7.

58. Ang GY, Yu CY, Balqis K, et al. Molecular evidence of cholera outbreak caused by a toxigenic Vibrio cholerae O1 El Tor variant strain in Kelantan, Malaysia. J Clin Microbiol. 2010;48(11):3963-9. 
Citation: Tasneem U, Yasin N, Nisa I, et al. Biofilm producing bacteria: A serious threat to public health in developing countries. J Food Sci Nutr. 2018;1(2):25-31.

59. Fraser B. Haiti still gripped by cholera as election looms. World Rep. 2010;376:1813-4.

60. Kirigia JM, Sambo LG, Yokouide A, et al. Economic burden of cholera in the WHO African region. BMC Int Health Hum Rights. 2009;9:8.

61. Satcher D. Emerging infections: getting ahead of the cure. Emerg Infect Dis. 1995;1(1)1-6.

62. Sack DA, Sack RB, Nair GB et al. Cholera. Lancet. 2004;363(9404):223-33.

63. Brands DA, Inman AE, Gerba CP, et al. Prevalence of Salmonella spp. in Oysters in the United States. Appl Environ Microbiol. 2005;71(2):893-7.

64. Kumar R, Surendran P, Thampuran N. Distribution and genetic characterization of Salmonella serovars isolated from tropical seafood of Cochin, India. J Appl Microbiol. 2009;106(2):515-24.

65. BakrWMK, Hazzah WA, Abaza AF. Detection of Salmonella and Vibrio species in some seafood in Alexandria. J Am Sci. 2011;7(9):663-8.

66. Amagliani G, Brandi G, Schiavano GF. Incidence and role of Salmonella in seafood Safety. Food Res Int. 2012;45(2):780-788.

67. Morbidity and MortalityWeekly Report (MMWR). Surveillance for Foodborne Disease Outbreaks - United States, 1998e2008. 2013.

68. Jami M, Ghanbari M, Zunabovic $M$, et al. Listeria monocytogenes in aquatic food productsda review. Compr Rev. Food Sci Food Saf. 2014;13(5):798-813.

69. Jallewar PK, Kalorey DR, Kurkijre NV, et al. Genotypic characterization of Listeria spp. Isolated from fresh water fish. Int J Food Microbiol. 2007;114(1):120-23.

70. Tompkin RB. Control of Listeria monocytogenes in the food-processing environment. $\mathrm{J}$ Food Prot. 2002;65(4):709-25.

71. Limsowtin GKY, Powell IB. Milk quality for cheese making. Aust J Dairy Technol. 1996;51:98-100.

72. Geetha R, Prasad V. Recent Advances in Controlling Bacterial Biofilms in Dairy Industry-A Review. Indian J Dairy Sci. 2011;64:267-77.

73. Kumar CG, Anand SK. Significance of microbial biofilms in food industry: a review. Int J Food Microbiol. 1998;42(12):9-27.

74. Flint S, Brooks JD, Elzen HV, et al. Biofilms in dairy manufacturing plant - a threat to product quality. Food Technol. 1997;27:61-4.

75. Sharma M, Anand SK, Prasad DN. In vitro propagation of mixed species biofilms using online consortia for dairy processing lines. Milchwissenschaft. 2003;58:270-273.

76. Waak E,ThamW, Danielsson TML. Prevalence and fingerprinting of Listeria monocytogenes strains isolated from raw whole milk in farm tanks and in dairy plant receiving tanks. App Environ Microbiol. 2002;68:(7)208595.

77. Salo S, Ehavald H, Raaska L et al. Microbial surveys in Estonian dairies. LWT Food Sci Tech. 2006;39(5):460-71.

78. Shaheen R, Svensson B, Andersson MA et al. Persistence strategies of Bacillus cereus spores isolated from dairy silo tanks. Food Microbiol. 2010;27(3):347-55.

79. Marchand S, Heylen K, Messens W, et al. Seasonal influence on heat-resistant proteolytic capacity of $\mathrm{P}$. lundensis and $\mathrm{P}$. fragi, predominant milk spoilers isolated from Belgian raw milk samples. Environ Microbiol. 2009;11(2):467-82.

80. De Jonghe V, Coorevits A, Van Hoorde K, et al. Influence of storage conditions on the growth of Pseudomonas species in refrigerated raw milk. Appl Environ Microbiol. 2011;77(2):460-70.

81. Zottola EA. Microbial attachment and biofilm formation: a new problem for the food industry. Food Technol. 1994;48:107-114.

82. Rogers AH. Molecular Oral Microbiology. Caister. Academic Press 2008;65-108.

83. Girard G, Bloemberg GV. Central role of quorum sensing in regulating the production of pathogenicity factors in Pseudomonas aeruginosa. Future Microbiol. 2008;3(1):97106.

84. Donlan RM. Biofilms and device-associated infections. Emerg Infect Dis. 2001;7(2):277-81.

85. Delle-Bovi RJ, Smits A, Pylypiw HM. Rapid method for the determination of total monosaccharide in Enterobacter cloacae strains using Fourier Transform Infrared Spectroscopy. Am J Analytical Chem. 2011;2:212-6.

86. Rodney M D. Biofilm Formation: A Clinically Relevant Microbiological Process. Clin Infect Dis. 2001;33(8):1387-92.

87. Ponnusamy P, Natarajan V, Sevanan M. In vitro biofilm formation by uropathogenic Escherichia coli and their antimicrobial susceptibility pattern. Asian Pac J Trop Med. 2012;5(3):210-3.

88. Tamilvanan S, Venkateshan N, Ludwing A. The potential of lipid- and polymer-based drug delivery carriers for eradicating biofilm consortia on devicerelated nosocomial infections. J Controlled Release. 2008;128(1):2-22.

89. Bavington C, Page C. Stopping bacterial adhesion: a novel approach to treating infections. Respiration 2005;72(4):335-44.

90. Kandulski A, Selgrad M, Malfertheiner P. Helicobacter pylori infection: a clinical overview. Dig Liver Dis 2008;40:619-26.

91. Guggenbichler PJ, Assadian O, Boeswald M, et al. Incidence and clinical implication of nosocomial infections associated with implantable biomaterials - catheters, ventilatorassociated pneumonia, and urinary tract infections. GMS Krankenhhyg Interdiszip. 2011;6(1):1-19. 
92. Glasmacher A, Engelhart S, Exner M. Infections from HPC organisms in drinkingwater amongst the immunocompromised, In: Heterotrophic Plate Counts and Drinkingwater Safety, Bartram J, Cotruvo J, Exner M, Fricker C \& Glasmacher A (ed) IWA Publishing, ISBN 1 84339025 6, London, UK. 2003:137-14.

93. Stickler DJ. Bacterial biofilms and the encrustation of urethral catheters. Biofouling. 1996;9(4):293-305.

94. Otto M. Staphylococcus epidermidis - the "accidental" pathogen. Nat Rev Microbiol. 2009;7:555-67.

95. Agarwal A, Singh KP, Jain A. Medical significance and management of staphylococcal biofilm. FEMS Immunol Med Microbiol. 2010;58(2):147-60.

96. Singh SB, Barrett JF. Empirical antibacterial drug discoveryFoundation in natural products. Biochem Pharmacol. 2006;71(7):1006-15.

97. Lerner PI. Producing penicillin. $N$ Engl $J$ Med. 2004;351(6):524.

98. Barriere SL. Clinical, economic and societal impact of antibiotic resistance. Expert Opin Pharmacother. 2015;16(2):151-3.

99. Costerton JW, Lewandowsi Z, Caldwell DE, et al. Microbial biofilms. Annu Rev Microbiol. 1995;49:711-45.

100. Diekema DJ, Pfaller MA, Schmitz FJ, et al. Survey of infections due to Staphylococcus species: Frequency of occurrence and antimicrobial susceptibility of isolates collected in the United States. Clin Infect Dis. 2001;32(2):S114-32.

101. Chambers HF, DeLeo FR. Waves of resistance: Staphylococcus aureus in the antibiotic era. Nat Rev Microbiol. 2009;7(9):629-41

102. Grundmann H, Ires-de-Sousa M, Boyce J, et al. Emergence and resurgence of meticillin-resistant Staphylococcus aureus as a public-health threat. Lancet. 2006;368(9538):874-85.
103. Lewis K. Persister cells, dormancy and infectious disease. Nat Rev Microbiol 2007;5(1):48-56.

104. Niels H, Thomas B, Michael G, et al. Antibiotic resistance of bacterial biofilms. 2010;35(4):322-33.

105. Midelet $\mathrm{G}$, Carpentier B. Impact of cleaning and disinfection agents on biofilm structure and on microbial transfer to a solid model food. J Appl Microbiol. 2004;97(2):262-70.

106. Simoes M, Simoes LC, Machado I et al. Control of flow-generated biofilms using surfactants - evidence of resistance and recovery. Food and Bioproducts Processing. 2006;84(C4):338-45.

107. Bremer PJ, Fillery S, McQuillan AJ. Laboratory scale clean-in-place (CIP) studies on the effectiveness of different caustic and acid wash steps on the removal of dairy biofilms. Int J Food Microbiol. 2006;106(3):254-62.

108. Hermoso JA, Garcia JL, Garcia P. Taking aim on bacterial pathogens: from phage therapy to enzybiotics. Curr Opin Microbiol. 2007;10(5):1-12.

109. Sandasi M, Leonard CM, Viljoen AM. The in vitro antibiofilm activity of selected culinary herbs and medicinal plants against Listeria monocytogenes. Lett Appl Microbiol. 2010;50(1):30-5.

110. Oliveira MMMd, Brugnera DF, Nascimento JAd, et al. Cinnamon essential oil and cinnamaldehyde in the control of bacterial biofilms formed on stainless steel surfaces. Eur Food Res Technol. 2012;234(5):821-32.

\section{*Correspondence to:}

Umber Tasneem

Department of Microbiology

Kohat University of Science and Technology

Khyber Pakhtunkhwa

Pakistan

Email: umbertasneem@yahoo.com 